\title{
Nonshivering thermogenesis capacity associated to mitochondrial DNA haplotypes and gender in the greater white-toothed shrew, Crocidura russula
}

\author{
PIERRE FONTANILLAS, ALINE DÉPRAZ, MAUD S. GIORGI and NiCOLAS PERRIN \\ Department of Ecology and Evolution, University of Lausanne, CH-1015 Lausanne, Switzerland
}

\begin{abstract}
A selection gradient was recently suggested as one possible cause for a clinal distribution of mitochondrial DNA (mtDNA) haplotypes along an altitudinal transect in the greater white-toothed shrew, Crocidura russula (Ehinger et al. 2002). One mtDNA haplotype (H1) rare in lowland, became widespread when approaching the altitudinal margin of the distribution. As $\mathrm{H} 1$ differs from the main lowland haplotype by several nonsynonymous mutations (including on ATP6), and as mitochondria play a crucial role in metabolism and thermogenesis, distribution patterns might stem from differences in the thermogenic capacity of different mtDNA haplotypes.

In order to test this hypothesis, we measured the nonshivering thermogenesis (NST) associated with different mtDNA haplotypes. Sixty-two shrews, half of which had the H1 haplotype, were acclimated in November at semioutdoor conditions and measured for NST throughout winter. Our results showed the crucial role of NST for winter survival in $C$. russula. The individuals that survived winter displayed a higher significant increase in NST during acclimation, associated with a significant gain in body mass, presumably from brown fat accumulation. The NST capacity (ratio of NST to basal metabolic rate) was exceptionally high for such a small species. NST was significantly affected by a gender $\times$ haplotype interaction after winter-acclimation: females bearing the $\mathrm{H} 1$ haplotype displayed a better thermogenesis at the onset of the breeding season, while the reverse was true for males. Altogether, our results suggest a sexually antagonistic cyto-nuclear selection on thermogenesis.
\end{abstract}

Keywords: brown fat, cyto-nuclear selection, metabolism, mtDNA, sexual antagonism, uncoupling protein

Received 7 June 2004; revision received 20 October 2004; accepted 29 October 2004

\section{Introduction}

Mitochondria provide most of the energy in animal cells through oxidative phosphorylation. The process involves four respiratory enzyme complexes, which form the electron transport chain, also known as the respiratory chain (Saraste 1999). These complexes are encoded by both nuclear DNA and mitochondrial DNA (mtDNA). Generally, the mitochondrial genome codes for 13 proteins, all participating in electron transport, two rRNAs, 22 mitochondrial-specific tRNAs and contains genes regulating transcription and

Correspondence: Pierre Fontanillas, Tel.: + 412169241 82; Fax: + 412169241 65; E-mail: pierre.fontanillas@unil.ch replication (the D-loop). Although evolutionary and population genetic studies often assume nearly neutral evolution (Fay et al. 2002; Ohta 2002), the important roles of all 13 mtDNA-encoded peptides in cellular energy production suggest that mtDNA variation could have significant metabolic and fitness consequences (William et al. 1995; Blier et al. 2001; Gerber et al. 2001; Rand 2001; Ballard \& Whitlock 2004). However, if statistical tests of neutral models based on the analysis of sequences have often been cited in support of the non-neutral evolution of mtDNA (e.g. Excoffier 1990; Ballard \& Kreitman 1994; Nachman et al. 1996; Templeton 1996; Weinreich \& Rand 2000; Ballard 2000; Doiron et al. 2002; Mishmar et al. 2003), direct evidence is scarce and mostly restricted to insects, especially 
Drosophila spp. (Nigro \& Prout 1990; Fos et al. 1990; Kambhampati et al. 1992; Kilpatrick \& Rand 1995; GarciaMartinez et al. 1998; James \& Ballard 2003; but see also Schizas et al. 2001; Staton et al. 2002 for copepods exposed to pesticide; Myres et al. 2000 for human neonatal death; Dionne et al. 1993; Murakami et al. 2002; Aoyama et al. 2003; for human respiratory capacity). Thus, the importance of selection in shaping regional mtDNA variation remains largely unknown (Ballard \& Whitlock 2004), in particular the evolutionary significance of mtDNA variation in climatic or thermal adaptations (Coskun et al. 2003; Mishmar et al. 2003; Elson et al. 2004; Ruiz-Pesini et al. 2004).

A recent study of mtDNA distribution along an altitudinal gradient in the greater white-toothed shrew (Crocidura russula) evidenced a pattern suggestive of selection (Ehinger et al. 2002). One haplotype (H1), rare in lowland populations $(<2 \%$ of individuals), became common at intermediate altitude (30\% of individuals), and dominant at higher elevation ( $>50 \%$ of individuals), close to the altitudinal margin of the species distribution [750-950 $\mathrm{m}$ above sea level ( $\mathrm{m}$ a.s.l.)]. Originating from Morocco, this shrew reached the Iberian Peninsula some 50000 вр (Cosson et al. in prep), then invaded more septentrional parts of western Europe (France, Switzerland and Germany) with the spread of agriculture. Its present distribution is limited by the cooler conditions that prevail at high latitudes and altitudes (Genoud 1985, 1995). In Switzerland, anthropophily is obligatory above $600 \mathrm{~m}$ of altitude (Genoud 1995), because over-winter survival is not possible without access to sources of warmth and food (invertebrates), provided by compost piles, stables and farms in rural habitats. Accordingly, C. russula has developed specific behavioural and physiological strategies to regulate its energy balance, including communal nesting and daily torpors when temperature drops and food is scarce (Vogel et al. 1979).

Cold acclimation in mammals primarily relies on an enhanced thermogenic capacity coupled with brown fat accumulation. Brown adipose tissue, characterized by its exceedingly high density of mitochondria, is the main site of nonshivering thermogenesis (NST), a physiological pathway allowing temperature maintenance during rest and temperature restoration during arousal from torpor (Hashimoto et al. 2002). In all tissues, mitochondrial oxidative phosphorylation uses energy derived from fuel combustion to create a proton gradient across the mitochondrial inner membrane. This intermediate form of energy is normally used by ATP synthase to generate ATP. In the brown fat, mitochondria display the additional ability to directly convert this gradient into heat. The key element of this energy dissipation capacity is the uncoupling protein 1 (UCP1), a mitochondrial inner membrane protein encoded by nuclear genes, which catalyses a highly regulated proton leak under the control of adrenergic receptors activated by noradrenalin (Nedergaard et al. 1999, 2001a). The proton flux activates the mitochondrial respiratory chain and increases the respiratory activity of the animal. Consequently, the NST capacity of an individual can easily be evaluated by measuring its maximal oxygen consumption triggered by the injection of noradrenalin.

Thermogenic capacity directly affects the ability of small mammals to survive periods of energy crisis, as underlined by direct evidence of selection (e.g. Hayes \& O'Connor 1999 on high-altitude deer mice, Peromyscus maniculatus) as well as seasonal variation of NST in response to temperature and photoperiod (e.g. Wang et al. 1999; Li et al. 2001; Nespolo et al. 2001; Deveci \& Egginton 2002). Seasonal acclimation is primarily acquired via adjustments of the mass of brown fat, the number of mitochondria in the brown fat and the number of UCP and/or adrenergic receptors (Klaus et al. 1988; Klingenspor et al. 1996; Yaffe 1999; Liu et al. 2001; Collins et al. 2001; Nedergaard et al. 2001b). Moreover, the activity of the respiratory chain can also be directly modulated by the regulation of transcription or translation of the mitochondrial genes (Klingenspor et al. 1996; Hittel \& Storey 2002).

Mitochondrial variants could thus affect the performances of the respiratory chain, and thereby contribute to climatic adaptation. The relative allocation of energy between heat and ATP production is determined by the relative efficiency of the oxidative phosphorylation and the uncoupled respiration (Ruiz-Pesini et al. 2004). In cold environments, mtDNA variants that reduce the coupling efficiency of oxidative phosphorylation and increase the efficiency of the uncoupling respiratory chain could be favoured. This hypothesis has been suggested by Mishmar et al. (2003) who examined regional variations of all 13 human mtDNA protein-coding genes. This study revealed that, even though the ATP6 gene is one of the most conserved mtDNA proteins, it had the highest amino acid variation, especially in the human lineages from the Arctic regions. However, this hypothesis of climatic adaptation of human mtDNA variants is debated (Elson et al. 2004; Ruiz-Pesini et al. 2004). In Drosophila, several studies also reported that the fitness of mtDNA variants is temperature dependent (Matsuura 1991, Matsuura et al. 1997; Tsujimoto et al. 1991; Doi et al. 1999).

In the present study, we tested whether mtDNA variants correlate with thermogenic capacity in C. russula, by comparing the maximal oxygen consumption induced by noradrenalin (an indirect measure of NST) of shrews carrying lowland vs. highland mitochondrial haplotypes (Ehinger et al. 2002). Sixty-two shrews, half of which with the H1 haplotype, were acclimated in semioutdoor conditions and measured for NST three times throughout winter: first in November (before winter acclimation), second in January at the peak of winter conditions, and third in March, at the onset of reproduction. The basal metabolic rate (BMR) was also assessed in March, in order to determine the NST capacity (ratio between NST and BMR). 
In order to precisely quantify the structural differences between $\mathrm{H} 1$ and L1 haplotypes (previously typed on $325 \mathrm{bp}$ of the D-loop region (Ehinger et al. 2002)), these two mtDNA genomes were also entirely sequenced.

\section{Materials and methods}

\section{Animals and winter acclimation}

Three of the five highland villages from the Swiss Jura analysed by Ehinger et al. (2002), namely Bassins, Marchissy and St George (750-950 m a.s.1.) were resampled in October 2001. Sixty-two individuals of Crocidura russula were captured with longworth traps prebaited with Tenebrio molitor larvae. Tissue samples were collected by toe clipping, then stored frozen at $-20{ }^{\circ} \mathrm{C}$ for DNA analysis. All shrews were taken to the University of Lausanne, and maintained in semioutdoor conditions between October 2001 and March 2002 in separate soil bottomed cages $(40 \times 25 \times 15 \mathrm{~cm})$ containing a nest filled with straw. Animals were fed daily a controlled amount of minced meat mixed with vitamins and T. molitor larvae, and provided with water ad libitum. Minimum and maximum ambient temperatures were registered daily.

\section{Genetic analysis}

Total DNA was extracted from 62 frozen toes following a salt/chloroform procedure modified from Miller et al. (1988) by adding one step of chloroform/isoamylalcohol extraction (24/1). As in Ehinger et al. (2002), we first analysed the HVII of the D-loop using the primers L16517 (Fumagalli et al. 1996) and H00651 (Kocher et al. 1989). Reactions were performed in a $50 \mu \mathrm{L}$ volume containing, $2 \mu \mathrm{M}$ of each primer, $200 \mu \mathrm{M}$ each dNTP, 2 units Taq DNA polymerase (QIAGEN), $1 \times \mathrm{PCR}$ (polymerase chain reaction) buffer with $1.5 \mathrm{~mm}$ of $\mathrm{MgCl}_{2}$ (QIAGEN) and $1 \times \mathrm{Q}$ solution (QIAGEN). The amplification program $\left(93^{\circ} \mathrm{C}\right.$ for $45 \mathrm{~s}, 52^{\circ} \mathrm{C}$ for $45 \mathrm{~s}$ and $72{ }^{\circ} \mathrm{C}$ for $60 \mathrm{~s}, 35$ cycles) was run on a DNA Thermal Cycler (Perkin Elmer). PCR products were purified

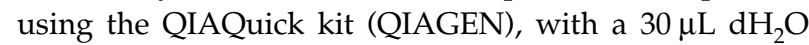
final elution volume. Sequencing was restricted to the single copy DNA between the primer L16517 and the R2 repeats (Fumagalli et al. 1996), yielding 325 bp sequence. Sequencing reactions were performed in a $7.5 \mu \mathrm{L}$ volume comprising $0.1 \mu \mathrm{M}$ primer, $3 \mu \mathrm{L}$ BigDye v3.0 mix (Applied Biosystems) and 2.5 $\mu \mathrm{L} \mathrm{PCR} \mathrm{product.} \mathrm{The} \mathrm{sequencing} \mathrm{pro-}$ gram was 3 min denaturation, 25 cycles of $96^{\circ} \mathrm{C}$ for $20 \mathrm{~s}$, $50{ }^{\circ} \mathrm{C}$ for $10 \mathrm{~s}$, and $60^{\circ} \mathrm{C}$ for $4 \mathrm{~min}$. Sequencing products were precipitated with ethanol, then run on a $6 \%$ polyacrylamide gel on an ABI 377 sequencer (Perkin Elmer). The sequences were aligned manually in Sequencher 3.0 (Gene Codes Corp.) and the haplotypes identified in MacClade 3.08 (Sinauer Associate).
Secondly, in order to fully characterize the two haplotypes $\mathrm{H} 1$ and L1, we used primer walking to sequence entirely the mtDNA genomes of two individuals from Ehinger et al. (2002), previously typed on the basis of the second hypervariable domain (HVII) of the mitochondrial control region (D-loop).

Finally, the distribution of a nonsynonymous mutation at position 8493 in the ATP6 gene, revealed by sequencing, was analysed among the 62 individuals used for the present study by restriction fragment length polymorphism (RFLP). A 131 bp region was amplified using the specific primers L8399 (ATTCAACTTATAGCGTTGGC) and H8530 (AATGAATGTAATGAGTGCGG). Reactions were performed in a $25 \mu \mathrm{L}$ volume containing, $2 \mu \mathrm{M}$ of each primer, $200 \mu \mathrm{M}$ each dNTP, 0.5 units Taq DNA polymerase (QIAGEN), $1 \times$ PCR buffer with $1.5 \mathrm{~mm}$ of $\mathrm{MgCl}_{2}$ (QIAGEN) and $1 \times \mathrm{Q}$ solution (QIAGEN). The amplification program $\left(93^{\circ} \mathrm{C}\right.$ for $45 \mathrm{~s}, 52{ }^{\circ} \mathrm{C}$ for $45 \mathrm{~s}$ and $72{ }^{\circ} \mathrm{C}$ for $60 \mathrm{~s}, 35$ cycles) was run on a DNA Thermal Cycler (Perkin Elmer). A small aliquot $(10 \mu \mathrm{L})$ of PCR reaction was treated with 1 units of Tru $1 \mathrm{I}$ (Fermentas) at $65{ }^{\circ} \mathrm{C}$ for $2 \mathrm{~h}$, and subsequently run on $1.5 \%$ agarose gel.

\section{Nonshivering thermogenesis (NST) and basal metabolic rate (BMR)}

We measured the NST of each individual three times: in November 2001 (before winter), in January 2002 (at the top of winter conditions), and in March 2002 (at the onset of reproduction). NST was recorded as the highest oxygen consumption over the 45-min period following subcutaneous injection of Chlorhydric-Noradrenalin (Fluka). The peak was clear and unambiguous in most cases. Measures were dropped in the few ambiguous cases (multiple peaks). The doses of noradrenalin (solution at $0.1 \mathrm{mg} / \mathrm{mL}$ ) were of $1.4 \mathrm{mg} / \mathrm{kg}$ body mass according to dose-dependent response curves (Sparti 1992). For the last measure of NST (after the winter), the noradrenalin doses were increased to $1.8 \mathrm{mg} /$ $\mathrm{kg}$ body mass to ensure a maximum metabolic response after acclimation.

Oxygen consumption was measured using an open-air flow respirometer (Depocas \& Hart 1957; Withers 2001). Animals were placed in a metabolic chamber (1.4 litre air volume) containing a small plastic shelter (reassuring effect). Ambient temperature was maintained at $20 \pm 0.1^{\circ} \mathrm{C}$ by submersing the metabolic chamber in a water bath. The metabolic chamber received dried air at a rate of $850 \mathrm{~mL} /$ min. The effluent air was sequentially passed through a column of $\mathrm{KOH}$ (in order to fix the expired $\mathrm{CO}_{2}$ ) and a silica gel column. The flow rate was controlled and measured continuously by a calibrated mass flow controller (model $5850 \mathrm{E}$, Brooks Instruments) which was connected to control and read out equipment (model 5878, Brooks Instruments). Finally, oxygen concentration was measured using an oxygen 
Table 1 Position of mutations between complete H1 and L1 mtDNA haplotypes [In grey: nonsynonymous mutations; In bold: transversions; Black square: the HVII region of the D-loop analysed in Ehinger et al. (2002) and in the present study]

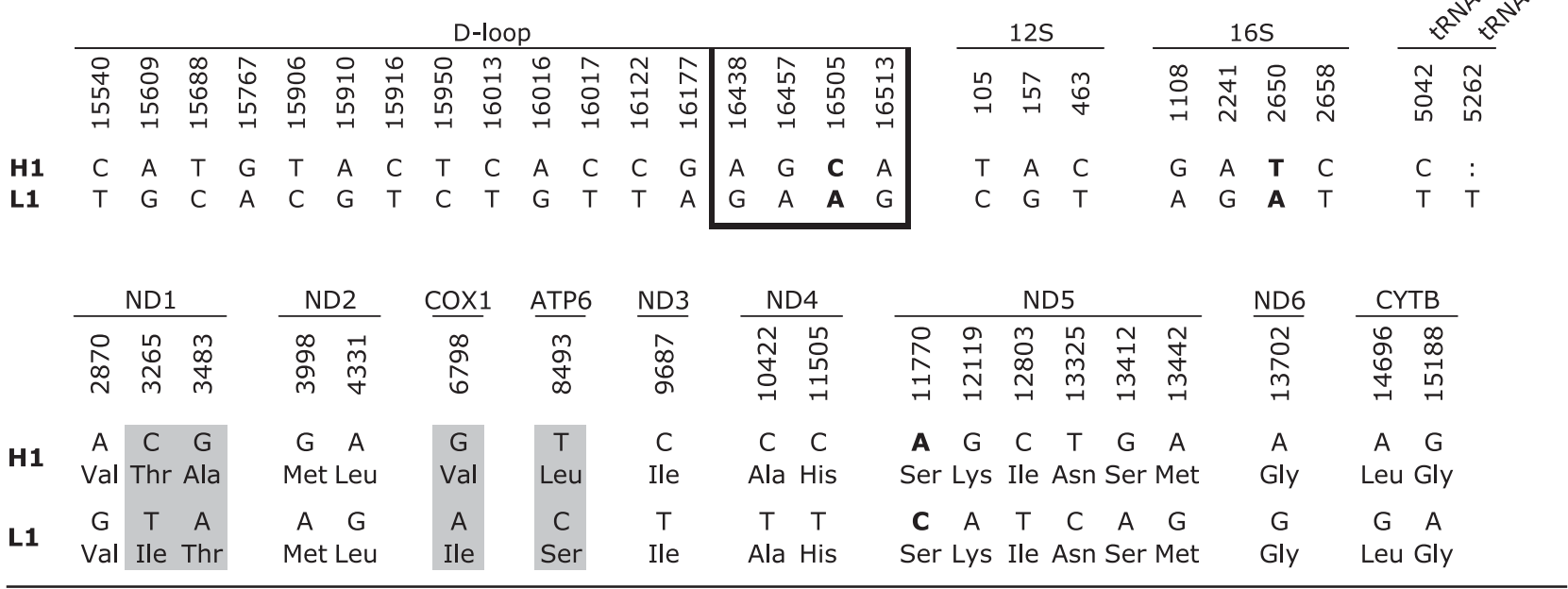

analyser (Gas purity analyser Xentra 4100, Servomex). The oxygen analyser was calibrated monthly using pure nitrogen gas (95\%) and pure oxygen gas (95\%). Oxygen concentration was recorded on paper by a potentiometric recorder (recorder 320, Scientific Instruments).

In March, the basal metabolism rate (BMR) was measured before analysis of NST. Each shrew was placed in the metabolic chamber in a water bath thermo-regulated at $30{ }^{\circ} \mathrm{C}$ (thermoneutral zone) and oxygen consumption was recorded for $4 \mathrm{~h}$. The animal was then injected with noradrenalin and replaced immediately in a metabolic chamber thermoregulated at $20^{\circ} \mathrm{C}$ and oxygen consumption measured for $45 \mathrm{~min}$, as previously described. BMR represented the lowest level of oxygen consumption maintained during at least $10 \mathrm{~min}$, excluding the first hour of measure in order to avoid any bias resulting from the stress of the animal. Body mass was determined before and after each measure on an electronic balance.

All statistical tests were computed with $\mathrm{R}$ (Ihaka \& Gentleman 1996).

\section{Results}

\section{Genetic analysis}

The sequence analysis of the mitochondrial control-region (HVII) revealed 32 shrews (13 females and 19 males) with the highland haplotype H1, vs. 29 shrews (16 females and 13 males) with the lowland haplotype L1, and one female with the haplotype L2, closely related to L1 (see Ehinger et al. 2002 for nomenclature).

The complete sequencing of two individuals (GenBank accession nos AY769263 and AY769264) from the Ehinger et al. (2002) study evidenced several structural differences between haplotypes H1 and L1 (Table 1). Over the whole of 17202 bp, 45 mutations were observed, among which one deletion and three transversions. Nine mutations affected rRNAs and tRNAs (which might play a role in the regulation of translation), 17 mutations concerned the D-loop, and 19 substitutions occurred in protein-encoding regions, of which four were nonsynonymous (two in ND1, one in COX1 and one in ATP6).

The RFLP analysis of the ATP6 gene among the 62 shrews used for the present study showed that all individuals with haplotype H1 displayed a Leucine (codon: TTA) whereas all individuals with haplotype L1 or L2 had a Serine (codon: TCA). For the remainder of this study, the single L2 individual will be pooled with the L1 haplotypes.

\section{Acclimation}

The acclimation period (Fig. 1) started with a mild and temperate phase until 10 December 2001, followed by a cold period from 10 December 2001 to 15 January 2002, then a warmer one until March. Our second series of NST analysis (10 January) thus occurred after 1 month of harsh conditions, while the third series followed nearly 2 months of mild and relatively stable temperatures.

\section{Body weight}

Body mass correlated with sex, males being of significantly heavier than females (c. 6\%) but not with mitochondrial haplotype (repeated-ANOvA; sex: $F_{1,58}=7.4, P<0.01$; haplotype: $F_{1,58}=0.8, P=0.37$; sex $\times$ haplotype: $\left.F_{1,58}=0.9, P=0.35\right)$. Body weight increased during acclimation (Fig. 2), being 


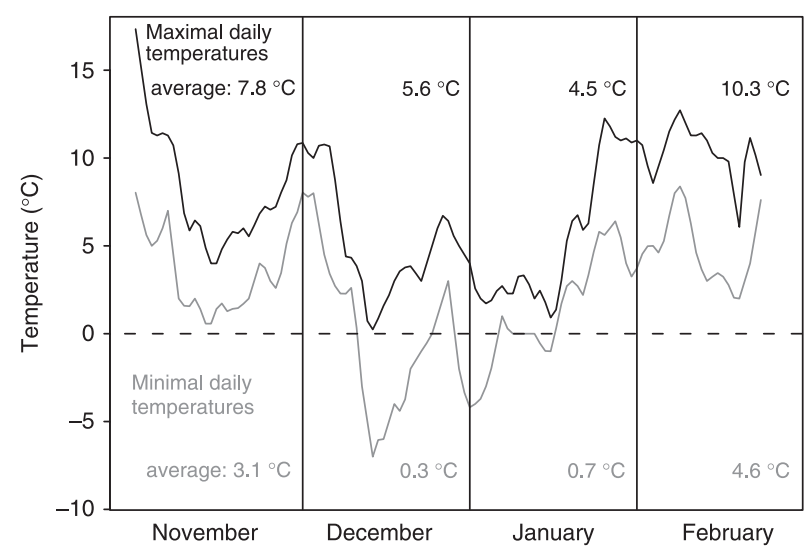

Fig. 1 Minimal and maximal daily temperatures recorded in the semioutdoor facilities during the cold-acclimation period (winter 2001-2002)

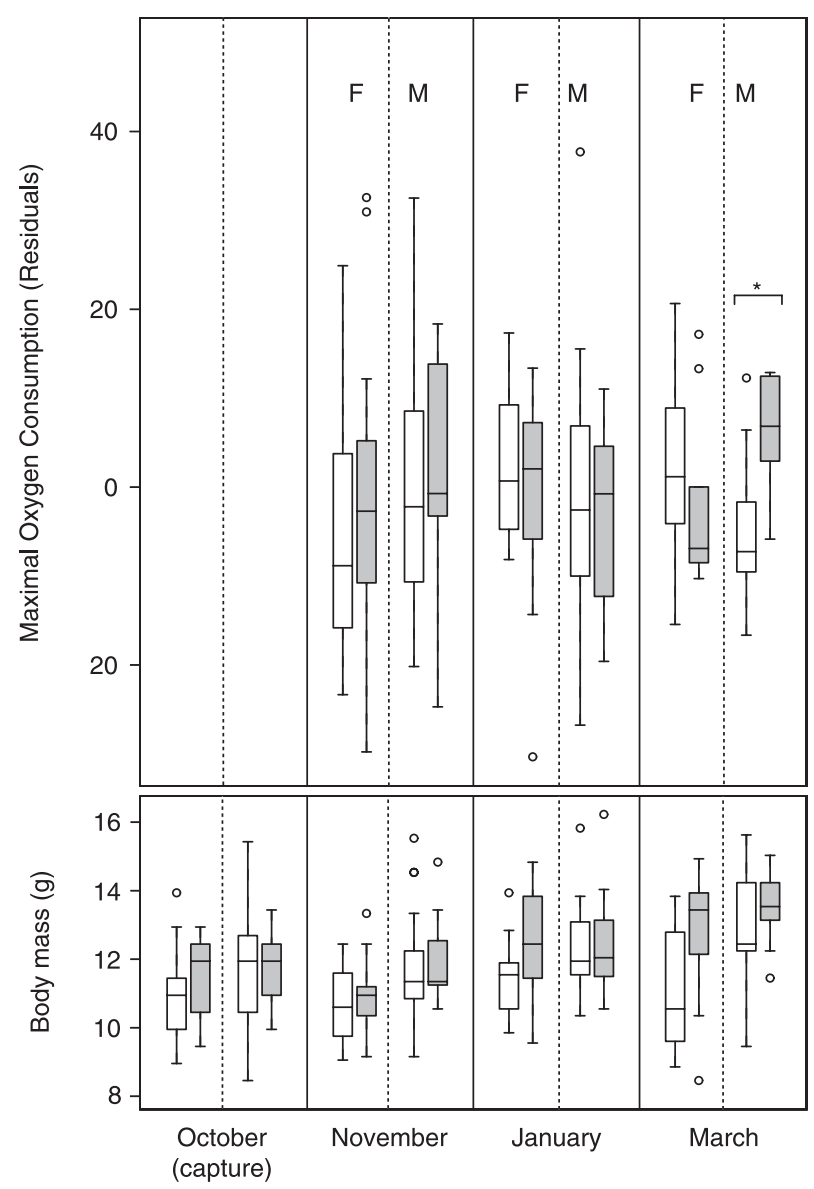

Fig. 2 Body mass and nonshivering thermogenesis (NST) measured as the maximum oxygen consumption after an injection of noradrenalin are given for the three series of measurements (November, January and March). White boxes for mtDNA haplotype $\mathrm{H} 1$ and black ones for mtDNA haplotype L1. F stands for female and $\mathrm{M}$ for male. Boxplots with median, first quartile and standard span $(1.5 \times$ interquartile range $)$ and outliers as circle. *: $P<0.05$.
$11.5 \mathrm{~g}$ on average in October-November, $12.3 \mathrm{~g}$ in January and $12.8 \mathrm{~g}$ in March. This increase was independent of sex and haplotype (repeated-ANova; month: $F_{3,137}=16, P<$ 0.001 ; month $\times$ sex: $F_{3,137}=2.3, P=0.08$; month $\times$ haplotype: $F_{3,137}=2, P=0.12$; month $\times$ sex $\times$ haplotype: $F_{3,137}=0.5$, $P=0.66)$.

\section{NST and BMR}

Maximal oxygen consumption increased significantly $(P<$ 0.05; multiple comparisons with Tukey's method) between November $(112 \pm 16 \mathrm{~mL} / \mathrm{h})$ and January $(156 \pm 19 \mathrm{~mL} / \mathrm{h})$, then stabilized (in March $153 \pm 19 \mathrm{~mL} / \mathrm{h}$ ). It also correlated positively with body mass (Fig. 3). The three slopes (for November, January and March) differed significantly from zero $(P<0.001)$ but also from each other (ANCOva; month: $F_{2,143}=118.8, P<0.001$; mass $\times$ month: $\left.F_{2,143}=4.9, P<0.001\right)$, mostly because of a large increase between November (4.81 $\mathrm{mL} \mathrm{O}_{2} \mathrm{~h}^{-1} \mathrm{~g}^{-1}$ ) and the following months (9.98 and $8.5 \mathrm{~mL} \mathrm{O}_{2} \mathrm{~h}^{-1} \mathrm{~g}^{-1}$, respectively). Thus, the NST increase between November and January was more pronounced in larger shrews, being $23 \%$ for a $9 \mathrm{~g}$ shrew $\left(100-123 \mathrm{~mL} \mathrm{O}_{2} \mathrm{~h}^{-1}\right)$ vs. $38 \%$ for a $13.5 \mathrm{~g}$ shrew $\left(122-168 \mathrm{~mL} \mathrm{O}_{2} \mathrm{~h}^{-1}\right)$. In other words, a $50 \%$ increase in body mass led to a $67 \%$ increase in thermogenic capacity. The explained variance $\left(R^{2}\right)$ also increased during acclimation, from 0.18 in November to 0.59 in January to 0.72 in March.

As the effect of body mass on NST changed throughout winter, the three series of measures were checked separately for a possible association between NST and sex or haplotypes, using body mass as a covariate (Fig. 2). No such association was found in November (ANCOVA; sex: $F_{1,53}=1.84, P=0.18$; haplotype: $F_{1,53}=0.50, P=0.48$; sex $\times$ haplotype: $F_{1.53}=0.25, P=0.62$ ) or January (ANCovA; sex: $F_{1,47}=0.70, P=0.41$; haplotype: $F_{1,47}=0.60, P=0.44$; sex $\times$ haplotype: $\left.F_{1,47}=0.007, P=0.93\right)$. By contrast, March exhibited a marginal effect of haplotype, and a significant interaction between sex and haplotype (ANCOVA; sex: $F_{1,34}$ $=0.005, P=0.95$; haplotype: $F_{1,34}=3.4, P=0.07$; $\operatorname{sex} \times$ haplotype: $\left.F_{134}=6.3, P=0.017\right)$. Haplotype $\mathrm{H} 1$ females had a higher relative oxygen consumption than $\mathrm{L} 1$ females, whereas $\mathrm{H} 1$ males showed a lower consumption than L1 males (Fig. 2). The pairwise difference between males was significant, and that between females marginally so, using multiple comparisons (Toothaker 1993) with Dunnett's method (H1 males vs. L1 males $P<0.05 ; \mathrm{H} 1$ females vs. L1 females $P<0.1$ ).

The BMR measured in March averaged $22.3 \mathrm{~mL} / \mathrm{h} \pm 4.1$. It was unrelated to body mass, sex and haplotype (ANOva; mass: $F_{1,44}=0.2, P=0.67$; sex: $F_{1,44}=0.02, P=0.84$; haplotype: $F_{1,44}=1.1, P=0.31$; sex $\times$ haplotype: $\left.F_{1,44}=0.6, P=0.44\right)$. The ratio of average NST to average BMR (153 and $22.3 \mathrm{~mL} / \mathrm{h}$, respectively) provided a very high value of $686 \%$ for the NST capacity in March. 

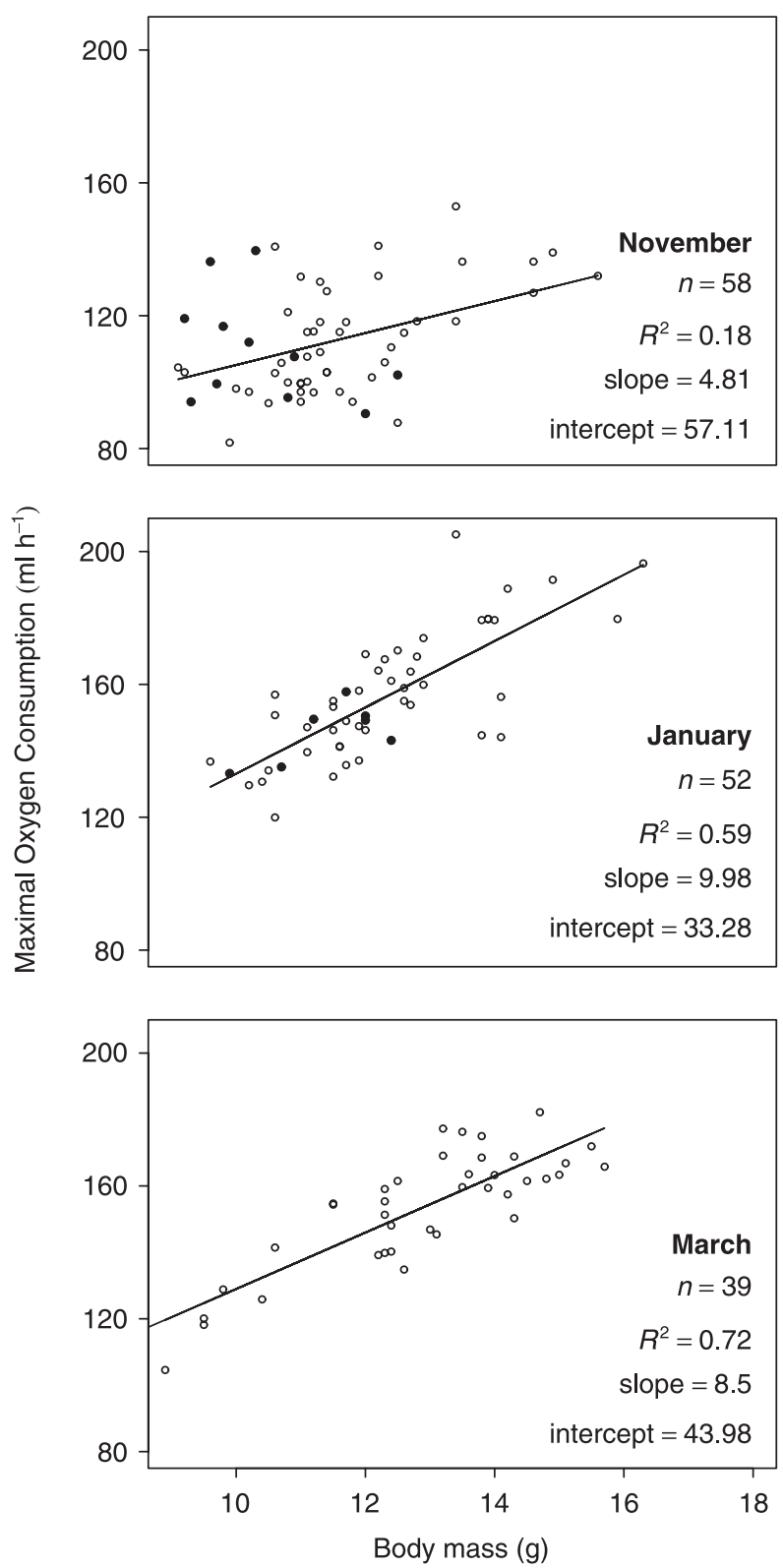

Fig. 3 Correlation between body mass and maximal oxygen consumption (a measure of nonshivering thermogenesis, NST) for the three series of measurements (November, January and March). Solid dots indicate shrews that died during winter acclimation.

\section{Mortality}

Thirteen shrews died during acclimation (three between November and January and 10 between January and March), none of which during NST or BMR measurements. This mortality (21\%), which is low compared to recorded field values at low altitudes (c. $40 \%$, see Bouteiller \& Perrin 2000; Reuter-Bouteiller \& Perrin 2005) was unrelated to sex or haplotype, but correlated with body mass (Fig. 3): the shrews that died during winter had a lower initial body mass. The trend was highly significant in November (ANovA; dead: $F_{1,56}=8, P<0.01$ ) and marginally so in January (ANOvA; dead: $F_{1,56}=2.9, P=0.09$ ). Excluding these individuals from statistical analyses did not change the relationship between NST and body mass.

\section{Discussion}

\section{Winter acclimation and body weight}

NST increased by $40 \%$ during winter acclimation, a considerable value for a species with a body mass of roughly $12 \mathrm{~g}$ (see Klaus et al. 1988; Merritt 1995; Harlow 1997; Li et al. 2001). Indeed, as the acclimation is primarily acquired via adjustments of the mass of brown fat, large species have a bigger capacity to increase the mass of brown fat and thus a better ability to increase their NST (Nedergaard et al. 2001a). The high value found here suggests that brown fat accumulation plays an essential role for winter survival in Crocidura russula. This is also supported by the higher mortality of lighter individuals, the $10 \%$ increase in body mass of surviving shrews, as well as the increase in both the correlation and slope of regression between NST and body mass throughout winter. Furthermore, the ratio between NST and BMR, which defines the NST capacity of a species, appears exceptionally large (c. 700\%). The NST capacities of small mammals usually do not exceed 350400\% (Shabtay et al. 2000; Li et al. 2001; Nespolo et al. 2001; Scantlebury et al. 2002). Altogether, these observations quantitatively confirm that NST, associated with the ability to enter torpor, is a crucial mechanism for C. russula to survive periods of energy crisis in winter.

\section{Complete mtDNA genome and ATP6}

The haplotypes $\mathrm{H} 1$ and L1 are clearly divergent $(0.26 \%)$, and differ structurally on three of their proteins. Structural differences, however, do not necessarily imply functional differences. The replacements of amino acid pairs $\mathrm{Thr} / \mathrm{Ile}$, $\mathrm{Thr} / \mathrm{Ala}$ and $\mathrm{Val} / \mathrm{lle}$, observed in ND1 and Cox1, are frequent in mtDNA genomes (Liò \& Goldman 2002), suggesting a weak effect, if any, on protein activity. By contrast, the transition between Leu/Ser observed in ATP6 is rare. This mutation allows a perfect discrimination between individuals $\mathrm{H} 1$ and L1, and thus potentially relates to the observed respiratory differences between these haplotypes.

\section{NST, mitochondrial haplotype and gender}

Can our results help to interpret the haplotype distribution described by Ehinger et al. (2002)? The response is not straightforward. Haplotype variants did affect NST in our experiments, but only at the onset of the breeding season, and only in interaction with sex. 
Gender differences in metabolism have already been firmly established, especially concerning the thermogenic capacity of adipose tissues (Quevedo et al. 1998; KaciubaUscilko \& Grucza 2001; Rodriguez et al. 2001; RodriguezCuenca et al. 2002; Monjo et al. 2003). Sex hormones have been pointed out as the main factor responsible for sexassociated differences in thermogenesis. Rodriguez et al. (2002), for instance, demonstrated that testosterone and progesterone have opposite effects on the expression of brown adipocyte uncoupling proteins (UCP) in mouse brown fat: testosterone inhibits the expression of UCP1 mRNA whereas progesterone stimulates it. A changing concentration of sexual hormones, related to the arousal of sexual activity, could account for the emergence of sex specificity in March, which marks the onset of the breeding season in C. russula.

Our findings, however, are more complex, pointing to sex-linked cyto-nuclear interactions (females had higher NST when carrying the H1 haplotype, while the reverse was true for males). Such interactions are not unexpected, since the different inheritance modes of nuclear and cytoplasmic genomes allow sexually antagonistic selection (Holland \& Rice 1999; Arnqvist \& Rowe 2002). Several mitochondrial disorders are known to show more severe effects in males than in females (Frank \& Hurst 1996). Rand et al. (2001) also showed sexually antagonistic cyto-nuclear interaction in Drosophila melanogaster: mtDNA variants appear 'good' in females but 'bad' in males, and vice versa. Although published studies on this topic are still scarce, the importance of such conflicts between sexes is probably underestimated (Ballard \& Whitlock 2004).

Mitochondrial haplotypes can undergo sex-specific selection if they bear direct effects on the phenotype of genders, or act on nuclear-encoded proteins imported into the mitochondrion. Alternatively, they might associate, through linkage disequilibrium, with nuclear genes involved in the sexual hormone pathway. Some disequilibrium between the mtDNA and the $X$ chromosome might occur because in mammals (as in fruit flies) the mtDNA is cotransmitted with two-thirds of the $\mathrm{X}$ chromosome copies but only half of the autosomal copies (Gibson et al. 2002). This hypothesis has some potential in our case because the $\mathrm{X}$ carries the main testosterone receptor gene (Brown et al. 1989; Brockdorff et al. 1991). This gene obviously promotes male phenotype differentiation but is also implicated in many other metabolic pathways.

Consequently, if haplotype $\mathrm{H} 1$ does directly or indirectly benefit female shrews in cold habitats through its higher thermogenic capacity, a sexually antagonistic selection might explain why this haplotype is not fixed at high-altitude localities. Theoretical (Babcock \& Asmussen 1996, 1998) as well as simulation studies (Rand et al. 2001) indicate that sexually antagonistic selection can maintain permanent joint cyto-nuclear interaction polymorphisms. The point must also be made, however, that high-altitude populations are smaller and undergo recurrent extinctions (Genoud \& Hausser 1979; Fontanillas et al. in prep), so that regular immigrants from lowland populations might prevent fixation of locally adapted haplotypes.

Owing to the complex interactions involved, our results must be taken as provisional. The role of mtDNA haplotypes on individual fitness remains speculative, and open for future research. In particular, the hypothesis of direct selection on the mtDNA could be further tested by extending the sampling of Ehinger et al. (2002) in order to confirm or falsify the altitudinal distribution on a wider geographical scale, and by measuring the thermogenic capacity of mitochondrial variants put into different nuclear backgrounds. Although provisional, however, our present results do promote the idea that gender differences reported in metabolism, in particular regarding thermogenic metabolism and UCP-related diseases (as obesity or diabetes, see Rodriguez \& Palou 2004), should be interpreted with caution, and checked for possible cyto-nuclear interactions.

\section{Acknowledgements}

We thank L.-J. Lawson Handley for useful comments on drafts of the manuscript and, M. Genoud and P. Vogel for technical supports and helpful discussions on NST analysis.

\section{References}

Aoyama M, Shidoji Y, Saimei M, Tsunawake N, Ichinose M (2003) Phenotypic linkage between single-nucleotide polymorphisms of beta (3)-adrenergic receptor gene and NADH dehydrogenase subunit-2 gene, with special reference to eating behavior. Biochemical and Biophysical Research Communications, 309, 261-265.

Arnqvist G, Rowe L (2002) Antagonistic coevolution between the sexes in a group of insects. Nature, 415, 787-789.

Babcock CS, Asmussen MA (1996) Effects of differential selection in the sexes on cytonuclear polymorphism and disequilibria. Genetics, 144, 839-853.

Babcock CS, Asmussen MA (1998) Effects of differential selection in the sexes on cytonuclear dynamics: life stages with sex differences. Genetics, 149, 2063-2077.

Ballard JWO (2000) Comparative genomics of mitochondrial DNA in members of the Drosophila melanogaster subgroup. Journal of Molecular Evolution, 51, 48-63.

Ballard JWO, Kreitman M (1994) Unraveling selection in the mitochondrial genome of Drosophila. Genetics, 138, 757-772.

Ballard JWO, Whitlock MC (2004) The incomplete natural history of mitochondria. Molecular Ecology, 13, 729-744.

Blier PU, Dufresne F, Burton RS (2001) Natural selection and the evolution of mtDNA-encoded peptides: evidence for intergenomic co-adaptation. Trends in Genetics, 17, 400-406.

Bouteiller C, Perrin N (2000) Individual reproductive success and effective population size in the greater white-toothed shrew Crocidura russula. Proceedings of the Royal Society of London Series B-Biology Sciences, 267, 701-705. 
Brockdorff N, Kay G, Smith S et al. (1991) High-density molecular map of the central span of the mouse X-chromosome. Genomics, 10, 17-22.

Brown CJ, Goss SJ, Lubahn DB et al. (1989) Androgen receptor locus on the human X-chromosome - regional localization to Xq11-12 and description of a DNA polymorphism. American Journal of Human Genetics, 44, 264-269.

Collins S, Cao WH, Daniel KW et al. (2001) Adrenoceptors, uncoupling proteins, and energy expenditure. Experimental Biology and Medicine, 226, 982-990.

Coskun PE, Ruiz-Pesini E, Wallace DC (2003) Control region mtDNA variants: longevity, climatic adaptation, and a forensic conundrum. Proceedings of the National Academy of Sciences of the United States of America, 100, 2174-2176.

Cosson J-F, Hutterer R, Libois M et al. (in prep) Phylogeography and population history of the greater white-toothed shrew Crocidura russula, over its whole range in western Europe and northwestern Africa.

Depocas F, Hart JS (1957) Use of the Pauling oxygen analyzer for measurement of oxygen consumption of animals in open-circuit systems and in a short-lag, closed-circuit apparatus. Journal of Applied Physiology, 10, 388-392.

Deveci D, Egginton S (2002) The effects of reduced temperature and photoperiod on body composition in hibernator and nonhibernator rodents. Journal of Thermal Biology, 27, 467-478.

Dionne FT, Turcotte L, Thibault MC et al. (1993) MitochondrialDNA sequence polymorphism, VO2max, and response to endurance training. Medicine and Science in Sports and Exercise, 25, 766-774

Doi A, Suzuki H, Matsuura ET (1999) Genetic analysis of temperature-dependent transmission of mitochondrial DNA in Drosophila. Heredity, 82, 555-560.

Doiron S, Bernatchez L, Blier PU (2002) A comparative mitogenomic analysis of the potential adaptive value of arctic charr mtDNA introgression in brook charr populations (Salvelinus fontinalis Mitchill). Molecular Biology and Evolution, 19, 19021909.

Ehinger M, Fontanillas P, Petit E, Perrin N (2002) Mitochondrial DNA variation along an altitudinal gradient in the greater white-toothed shrew, Crocidura russula. Molecular Ecology, 11, 939-945.

Elson JL, Turnbull DM, Howell N (2004) Comparative genomics and the evolution of human mitochondrial DNA: assessing the effects of selection. American Journal of Human Genetics, 74, 229238.

Excoffier L (1990) Departure of human mitochondrial-DNA variation from neutral expectations - an alternative explanation Reply. Journal of Molecular Evolution, 31, 347-350.

Fay JC, Wyckoff GJ, Wu CI (2002) Testing the neutral theory of molecular evolution with genomic data from Drosophila. Nature, 415, 1024-1026.

Fontanillas P, Petit E, Perrin N (in prep) Local extinction effects on sex-specific dispersal rates and genetic diversity in shrew (Crocidura russula) metapopulation.

Fos M, Dominguez MA, Latorre A, Moya A (1990) MitochondrialDNA evolution in experimental populations of Drosophila subobscura. Proceedings of the National Academy of Sciences of the United States of America, 87, 4198-4201.

Frank SA, Hurst LD (1996) Mitochondria and male disease. Nature, 383, 224-224.

Fumagalli L, Taberlet P, Favre L, Hausser J (1996) Origin and evolution of homologous repeated sequences in the mitochondrial
DNA control region of shrews. Molecular Biology and Evolution, 13, 31-46.

Garcia-Martinez J, Castro JA, Ramon M, Latorre A, Moya A (1998) Mitochondrial DNA haplotype frequencies in natural and experimental populations of Drosophila subobscura. Genetics, 149, 1377-1382.

Genoud M (1985) Ecological energetics of two European shrews: Crocidura russula and Sorex coronatus (Soricidae, Mammalia). Journal of Zoology, London, 207, 63-85.

Genoud M (1995) Crocidura russula. In: Mammifères de Suisse (ed. Hausser J), pp. 49-53. Birkhäuser-Verlag, Basel.

Genoud M, Hausser J (1979) Ecology of a Crocidura russula population in a rural mountain habitat. Terre ET Vie-Revue d'Ecologie Appliquée, 33, 539-554.

Gerber AS, Loggins R, Kumar S, Dowling TE (2001) Does nonneutral evolution shape observed patterns of DNA variation in animal mitochondrial genomes? Annual Review of Genetics, 35, 539-566.

Gibson JR, Chippindale AK, Rice WR (2002) The X chromosome is a hot spot for sexually antagonistic fitness variation. Proceedings of the Royal Society of London Series B-Biology Sciences, 269, 499505.

Harlow HJ (1997) Winter body fat, food consumption and nonshivering thermogenesis of representative spontaneous and facultative hibernators: The white-tailed prairie $\mathrm{dog}$ and black-tailed prairie dog. Journal of Thermal Biology, 22, 21-30.

Hashimoto M, Gao BH, Kikuchi-Utsumi K, Ohinata H, Osborne PG (2002) Arousal from hibernation and BAT thermogenesis against cold: central mechanism and molecular basis. Journal of Thermal Biology, 27, 503-515.

Hayes JP, O'Connor CS (1999) Natural selection on thermogenic capacity of high-altitude deer mice. Evolution, 53, 1280-1287.

Hittel DS, Storey KB (2002) Differential expression of mitochondriaencoded genes in a hibernating mammal. Journal of Experimental Biology, 205, 1625-1631.

Holland B, Rice WR (1999) Experimental removal of sexual selection reverses intersexual antagonistic coevolution and removes a reproductive load. Proceedings of the National Academy of Sciences of the United States of America, 96, 5083-5088.

Ihaka R, Gentleman R (1996) R: a language for data analysis and graphics. Journal of Computation Graphical Statistic, 5, 299-314.

James AC, Ballard JWO (2003) Mitochondrial genotype affects fitness in Drosophila simulans. Genetics, 164, 187-194.

Kaciuba-Uscilko H, Grucza R (2001) Gender differences in thermoregulation. Current Opinion in Clinical Nutrition and Metabolic Care, 4, 533-536.

Kambhampati S, Rai KS, Verleye DM (1992) Frequencies of mitochondrial-DNA haplotypes in laboratory cage populations of the mosquito, Aedes albopictus. Genetics, 132, 205-209.

Kilpatrick ST, Rand DM (1995) Conditional hitchhiking of mitochondrial-DNA - Frequency-shifts of Drosophila melanogaster mtDNA variants depend on nuclear genetic background. Genetics, 141, 1113-1124.

Klaus S, Heldmaier G, Ricquier D (1988) Seasonal acclimation of Bank Voles and Wood Mice - Nonshivering thermogenesis and thermogenic properties of brown adipose-tissue mitochondria. Journal of Comparative Physiology B-Biochemical Systemic and Environmental Physiology, 158, 157-164.

Klingenspor M, Ivemeyer M, Wiesinger $\mathrm{H}$ et al. (1996) Biogenesis of thermogenic mitochondria in brown adipose tissue of Djungarian hamsters during cold adaptation. Biochemical Journal, 316, 607-613. 
Kocher TD, Thomas WK, Meyer A et al. (1989) Dynamics of mitochondrial-DNA evolution in animals - amplification and sequencing with conserved primers. Proceedings of the National Academy of Sciences of the United States of America, 86, 6196-6200.

Li QF, Sun RY, Huang CX et al. (2001) Cold adaptive thermogenesis in small mammals from different geographical zones of China. Comparative Biochemistry and Physiology a-Molecular and Integrative Physiology, 129, 949-961.

Liò P, Goldman N (2002) Modeling mitochondrial protein evolution using structural information. Journal of Molecular Evolution, 54, 519-529.

Liu XT, Li QF, Lin QS, Sun RY (2001) Uncoupling protein1 mRNA, mitochondrial GTP-binding, and T-4 5'-deiodinase of brown adipose tissue in euthermic Daurian ground squirrel during cold exposure. Comparative Biochemistry and Physiology aMolecular and Integrative Physiology, 128, 827-835.

Matsuura ET (1991) Selective transmission of mitochondrial-DNA in Drosophila. Japanese Journal of Genetics, 66, 683-700.

Matsuura ET, Tanaka YT, Yamamoto N (1997) Effects of the nuclear genome on selective transmission of mitochondrial DNA in Drosophila. Genes and Genetic Systems, 72, 119-123.

Merritt JF (1995) Seasonal thermogenesis and changes in bodymass of masked shrews, Sorex cinereus. Journal of Mammology, 76, 1020-1035.

Miller SA, Dykes DD, Polesky HF (1988) A simple salting out procedure for extracting DNA from human nucleated cells. Nucleic Acids Research, 16, 1215-1215.

Mishmar D, Ruiz-Pesini E, Golik P et al. (2003) Natural selection shaped regional mtDNA variation in humans. Proceedings of the National Academy of Sciences of the United States of America, 100, 171-176.

Monjo M, Rodriguez AM, Palou A, Roca P (2003) Direct effects of testosterone, 17 beta-estradiol, and progesterone on adrenergic regulation in cultured brown adipocytes: potential mechanism for gender-dependent thermogenesis. Endocrinology, 144, 49234930.

Murakami H, Ota A, Simojo H et al. (2002) Polymorphisms in control region of mtDNA relates to individual differences in endurance capacity or trainability. Japanese Journal of Physiology, 52, 247-256.

Myres JE, Malan M, Shumway JB et al. (2000) Haplogroupassociated differences in neonatal death and incidence of low birth weight at elevation: a preliminary assessment. American Journal of Obstetrics and Gynecology, 182, 1599-1603.

Nachman MW, Brown WM, Stoneking M, Aquadro CF (1996) Nonneutral mitochondrial DNA variation in humans and chimpanzees. Genetics, 142, 953-963.

Nedergaard J, Golozoubova V, Matthias A et al. (2001a) UCP1: the only protein able to mediate adaptive non-shivering thermogenesis and metabolic inefficiency. Biochimica ET Biophysica Acta-Bioenergetica, 1504, 82-106.

Nedergaard J, Golozoubova V, Matthias A et al. (2001b) Life without UCPI: mitochondrial, cellular and organismal characteristics of the UCPI-ablated mice. Biochemical Society Transactions, 29, 756-763.

Nedergaard J, Matthias A, Golozoubova V, Jacobsson A, Cannon B (1999) UCP1: The original uncoupling protein - and perhaps the only one? New perspectives on UCP1, UCP2, and UCP3 in the light of the bioenergetics of the UCP1-ablated mice. Journal of Bioenergetics and Biomembranes, 31, 475-491.

Nespolo RF, Opazo JC, Bozinovic F (2001) Thermal acclimation and nonshivering thermogenesis in three species of South
American rodents: a comparison between arid and mesic habitats. Journal of Arid Environments, 48, 581-590.

Nigro L, Prout T (1990) Is there selection on RFLP differences in mitochondrial DNA. Genetics, 125, 551-555.

Ohta T (2002) Near-neutrality in evolution of genes and gene regulation. Proceedings of the National Academy of Sciences of the United States of America, 99, 16134-16137.

Quevedo S, Roca P, Pico C, Palou A (1998) Sex-associated differences in cold-induced UCP1 synthesis in rodent brown adipose tissue. Pflugers Archiv-European Journal of Physiology, 436, 689-695.

Rand DM (2001) The units of selection on mitochondrial DNA. Annual Review of Ecology and Systematics, 32, 415-448.

Rand DM, Clark AG, Kann LM (2001) Sexually antagonistic cytonuclear fitness interactions in Drosophila melanogaster. Genetics, 159, 173-187.

Reuter-Bouteiller C, Perrin N (in press) Sex-specific selective pressures on body mass in the greater white-toothed shrew, Crocidura russula. Journal of Evolutionary Biology.

Rodriguze AM, Monjo M, Roca P, Palou A (2002) Opposite actions of testosterone and progesterone on UCP1 rnRNA expression in cultured brown adipocytes. Cellular and Molecular Life Sciences, 59, 1714-1723.

Rodriguez AM, Palou A (2004) Uncoupling proteins: genderdependence and their relation to body weight control. International Journal of Obesity, 28, 327-329.

Rodriguez AM, Quevedo-Coli S, Roca P, Palou A (2001) Sexdependent dietary obesity, induction of UCPs, and leptin expression in rat adipose tissues. Obesity Research, 9, 579-588.

Rodriguez-Cuenca S, Pujol E, Justo R et al. (2002) Sex-dependent thermogenesis, differences in mitochondrial morphology and function, and adrenergic response in brown adipose tissue. Journal of Biological Chemistry, 277, 42958-42963.

Ruiz-Pesini E, Mishmar D, Brandon M, Procaccio V, Wallace DC (2004) Effects of purifying and adaptive selection on regional variation in human mtDNA. Science, 303, 223-226.

Saraste M (1999) Oxidative phosphorylation at the fin de siecle. Science, 283, 1488-1493.

Scantlebury M, Afik D, Shanas U, Haim A (2002) Comparative nonshivering thermogenesis in adjacent populations of the common spiny mouse (Acomys cahirinus) from opposite slopes: the effects of increasing salinity. Journal of Comparative Physiology B-Biochemical Systemic and Environmental Physiology, 172, 1-5.

Schizas NV, Chandler GT, Coull BC, Klosterhaus SL, Quattro JM (2001) Differential survival of three mitochondrial lineages of a marine benthic copepod exposed to a pesticide mixture. Environmental Science and Technology, 35, 535-538.

Shabtay A, Haim A, Arad Z (2000) Metabolic rate and thermoregulation in the Macedonian mouse Mus macedonicus. Israel Journal of Zoology, 46, 305-312.

Sparti A (1992) Thermogenic capacity of shrews (Mammalia, Soricidae) and its relationship with basal rate of metabolism. Physiological Zoology, 65, 77-96.

Staton JL, Schizas NV, Klosterhaus SL et al. (2002) Effect of salinity variation and pesticide exposure on an estuarine harpacticoid copepod, Microarthridion littorale (Poppe), in the southeastern US. Journal of Experimental Marine Biology and Ecology, 278, 101110.

Templeton AR (1996) Contingency tests of neutrality using intra/ interspecific gene trees: The rejection of neutrality for the evolution of the mitochondrial cytochrome oxidase II gene in the hominoid primates. Genetics, 144, 1263-1270. 
670 PIERRE FONTANILLAS ET AL.

Toothaker LE (1993) Multiple Comparison Procedures. Sage Publications, London.

Tsujimoto Y, Niki Y, Matsuura ET (1991) Further study on selective transmission of mitochondrial DNA in heteroplasmic lines of Drosophila melanogaster. Japanese Journal of Genetics, 66, 609-616.

Vogel P, Burgener M, Lardet JP, Genoud M, Frey H (1979) Influence de la température et de la nourriture disponible sur la torpeur chez la musaraigne musette (Crocidura russula) en captivité. Bulletin de la Société Vaudoise Des Sciences Naturelles, 74, 325-332.

Wang D, Sun R, Wang Z, Liu J (1999) Effects of temperature and photoperiod on thermogenesis in plateau pikas (Ochotona curzoniae) and root voles (Microtus oeconomus). Journal of Comparative Physiology B-Biochemical Systemic and Environmental Physiology, 169, 77-83.

Weinreich DM, Rand DM (2000) Contrasting patterns of nonneutral evolution in proteins encoded in nuclear and mitochondrial genomes. Genetics, 156, 385-399.
William J, Ballard O, Kreitman M (1995) Is mitochondrial-DNA a strictly neutral marker. Trends in Ecology and Evolution, 10, 485-488.

Withers PC (2001) Design, calibration and calculation for flowthrough respirometry systems. Australian Journal of Zoology, 49, $445-461$.

Yaffe MP (1999) The machinery of mitochondrial inheritance and behavior. Science, 283, 1493-1497.

Pierre Fontanillas is interested by statistical methods allowing inferences of demographic parameters and in molecular basis of adoptive evolutionary processes. This study is a part of the diploma work of Aline Dépraz, who now works on evolution and population genetics of Snails. Nicolas Perrin's research deals mainly with the ecology and evolution of dispersal; genetic markers are used to derive inferences on population processes. 